\title{
Tip 2 Diyabetli Bireylerin Hastalık Yönetiminde Karşılaştıkları Engellerin Değerlendirilmesi
}

\author{
Evaluation of the Obstacles Encountered by the Patients with Type 2 Diabetes in Disease
}

Management

\author{
Şuheda ÜSTÜNDAĞ 1 A,B,C,D,E,F@, Nuray DAYAPOĞLU² A,B,D,E,G \\ ${ }^{1}$ Erzurum Şehir Hastanesi Palandöken Ek Hizmet Binas1, Erzurum, Türkiye \\ ${ }^{2}$ Atatürk Üniversitesi Hemșirelik Fakültesi İç Hastalıkları Hemșireliği Ana Bilim Dalı, Erzurum, Türkiye
}

ÖZ

\begin{abstract}
Amaç: Araştırma Tip 2 diyabet hastalarının hastalık yönetiminde karşılaştıkları engelleri ve bu engelleri etkileyen faktörleri değerlendirmek amaciyla yapılmıştır.

Yöntem: Tanımlayıcı türde yapılan bu araştırmanın verileri, Atatürk Üniversitesi Sağlık Araştırma ve Uygulama Merkezinin Endokrinoloji klinik ve polikliniğinde, araştırma kriterlerine uyan 120 Tip 2 diyabet hastasından elde edilmiştir. Verilerin toplanmasında Hasta Tanıtıcı Formu ve Diyabette Engeller Ölçeği kullanılmıştır. Verilerin analizi bilgisayar ortamında SPSS 22.00 istatistik paket programı ile yapılmıştır.

Bulgular: Çalışmaya alınan hastaların Diyabette Engeller Ölçeği alt boyutlarından aldıkları puan ortalamaları incelendiğinde; en yüksek puan ortalamasının 9.55 4.53 puan ile Diyabette Başa Çıkma Engelleri alt boyutuna, en düşük puan ortalamasının ise -1.76 \pm 6.13 puan ile İlaç Kullanım Engelleri alt boyutuna ait olduğu bulunmuştur. Hastaların cinsiyeti, yaşı, medeni durumu, eğitim durumu ve ekonomik durumu gibi sosyodemografik özellikleri ile tanı süresi, tedavi şekli, tedaviye uyum algısı, kan şekerine bakma durumu, diyete uyum algısı, egzersiz yapma durumu, doktora gitme sıklığı, diyabete bağlı komplikasyon gelişme durumu ve ek hastalık olma durumu gibi hastalığa ilişkin özellikleri ile Diyabette Engeller Ölçeği alt gruplarına ait puan ortalamaları arasında istatistiksel olarak anlamlı bir fark olduğu tespit edilmiştir $(\mathrm{p}<0.05)$.

Sonuç: Tip 2 diyabet hastalarının bazı sosyodemografik ve hastalığa ilişkin özelliklerinin diyabet yönetiminde karşılaşılan engelleri etkilemektedir. Tip 2 diyabet hastalarının en fazla diyabetle başa çıkmada engel yaşadıkları ve ilaç kullanımında daha az engel yaşadıkları sonucuna varılmıştır.
\end{abstract}

Anahtar Kelimeler: Diyabette engeller, Hemşirelik, Tip 2 diyabet.

ABSTRACT

Objective: The research was conducted to investigate the obstacles encountered by patients with Type 2 diabetes in disease management and to evaluate the factors affecting these obstacles.

Methods: The data for this descriptive type research were collected from 120 patients with Type 2 diabetes, who met the research inclusion criteria, in the Endocrinology clinic and outpatient clinic of Atatürk University Health Research and Application Center. Patient Introductory Information Form and Diabetes Obstacles Questionnaire were used for data collection. The analysis of the data was performed by SPSS 22.00 statistical program in computer environment.

Results: Considering the mean scores of the studied patients in the sub-scales of the Diabetes Obstacles Questionnaire, it was found that the highest mean score was $9.55 \pm 4.53$ points in the Diabetes Coping Obstacles sub-scale, and the lowest mean score was $-1.76 \pm 6.13$ points in the Drug Use Obstacles sub-scale. A statistically significant difference was found between the mean Diabetes Obstacles Questionnaire sub-scale scores and patients' sociodemographic characteristics, such as gender, age, marital status, educational status, and economic status, and disease-related characteristics, such as the time of diagnosis, treatment modality, adherence to treatment perception, blood sugar control, adherence to diet perception, exercise status, frequency of doctor visits, diabetes-related complications, and comorbid diseases $(\mathrm{p}<0.05)$.

Sorumlu Yazar: Nuray DAYAPOĞLU

Atatürk Üniversitesi Hemşirelik Fakültesi İç Hastalıkları Hemşireliği Ana Bilim Dalı, Erzurum, Türkiye

nuraydayapoglu@hotmail.com

Geliş Tarihi: 17.04.2021 - Kabul Tarihi: 11.08.2021

Yazar Katkıları: A) Fikir/Kavram, B) Tasarım, C) Veri Toplama ve/veya İşleme, D) Analiz ve/veya Yorum, E) Literatür

Taraması, F) Makale Yazımı, G) Eleştirel İnceleme 
Conclusion: Some sociodemographic and disease-related characteristics of the patients with Type 2 diabetes affect the obstacles encountered in diabetes management. It was concluded that patients with Type 2 diabetes experience the most obstacles in coping with diabetes and have fewer barriers in drug use.

Key words: Obstacles in diabetes, nursing, type-2 diabetes.

\section{GíRiş}

Diyabet, insülin eksikliği veya insülin etkisindeki defektler sonucu meydana gelen, karbonhidrat, yăg ve proteinin vücutta etkin bir şekilde kullanılmamasıyla ortaya çıkan, kompleks, kronik bir hastalıktır (1). Ciddi ve ilerleyici bir hastalık olmakla beraber istenilen düzeyde kontrol sağlanamadığında bireyle birlikte toplumu da büyük oranda etkileyen bir sorundur (2). International Diabetes Federation (IDF) 2019 verilerine göre dünyada 463 milyon olan diyabetli sayısının 2045 yılında \%51'lik bir artışla 700 milyona ulaşacağ öngörülmektedir. Ülkemizde ise 2010 yılında 3.679 milyon olan diyabetli sayısı 2019 yılında 6.592 milyona yükselmiş olup, 2010 yılında \%8 olan diyabet prevelansı 2019'da \%11.1 olmuştur (3).

Diyabet prevelansı yaşam tarzı değişikliği ve nüfusun yaşlanmasına bağlı olarak gelişen hareketsiz yaşam ve obezite sonucu artmaktadır (4). Diyabetin neden olduğu komplikasyonlar sonucu bireyde çeşitli organ ve işlev kayıpları meydana gelmektedir. Bunun sonucu olarak yaşam süresi ve kalitesi etkilenmekte, tüm toplumu etkileyen sosyal ve ekonomik kayıplar meydana gelmektedir $(5,6)$. Tüm bu nedenlerden dolayı diyabetin engellenmesi ve eğer gelişmişse kontrol altında tutulması oldukça önemlidir. İstendik düzeyde kontrol edilemeyen diyabet birçok akut ve kronik komplikasyonlara neden olmaktadır. Özellikle yıllar içinde gelişen mikrovasküler ve makrovasküler komplikasyonlar bireyin yaşamını ciddi anlamda etkilemektedir (7). Bundan dolayı da hastalık sürekli izlem ve bakım gerektiren bir durum olarak karşımıza çıkmaktadır (8). Diyabet yönetimi; beslenme tedavisi, düzenli egzersiz programı, hastanın kendini izlemesi, ilaç tedavisi ve hasta eğitimini içermektedir. Tüm bunların koordinasyonu ve sentezi ile başarılı bir diyabet yönetimi sağlanmış olur.

Diyabet yönetiminin temelini hastaların kendi sağlıkları ile ilgili tutum ve davranışları belirlemektedir (9). Bu nedenle diyabet hastasının bireysel yönetimi, tedavi ve bakımına etkin katılımını ve uyumunu sağlaması açısından önemlidir (9-11). Diyabet yönetiminin başarılı bir şekilde gerçekleştirilmesi için ise bu hastaların bilgi, beceri ve olumlu tutumlara sahip olması gerekmektedir (12). Ancak hastalar bireysel yönetimlerinde bazı engellerle karşılaşmaktadırlar. Bunlar ilaç engelleri, kendini izleme engelleri, bilgi ve inanç engelleri, tanıdaki engeller, sağlık profesyonelleri ile ilişkilerde engeller, yaşam tarzı değişikliği engelleri, diyabetle başa çıkma engelleri ve öneri ve destek almada engellerdir (13).

Bireyin karşılaştığ bu engellerle yeterince baş edememesi kötü bir diyabet yönetimine neden olmaktadır. Diyabetin yönetiminde en önemli noktalardan biri kendi kendine kan şekeri izlemidir. Amerikan Diyabet Birliği (ADA), kendi kendine kan şekeri izleminin, glisemik kontrolün sağlanmasında, hiperglisemi ve asemptomatik hipogliseminin önüne geçilmesinde önemli olduğunu belirtmektedir (14). HbA1c düzeyleri kan şekeri ölçümünü daha sık yapan hastalarda daha düşük bulunmuştur (15). Diyabet yönetimi kötü olan ve sürekli hiperglisemi yaşayan hastalarda HbA1c değerinde artış olmaktadır. HbA1c değerinde görülen \%1'lik artış ise komplikasyonların oluşumunda risk olarak kabul edilmektedir (16). Başka bir çalışmada da diyabetli bireylerin en çok sorun yaşadıkları konunun diyetlerine uyum olduğu saptanmıştır 
(17). Sıkı diyet programlarının hastalara sunulması uyumu zorlaştıran önemli nedenlerdendir (18). Diyetine dikkat eden hastaların dikkat etmeyenlere oranla hastalığa uyumunun daha iyi olduğu saptanmıştır (19). El-Kebbi ve arkadaşları tarafından Afro-Amerikan diyabetlileri ile yapılan bir çalışmada; aile desteğinin az olması, diyette bulunan besinlerdeki düşük yağ ve şeker içeriğinden dolayı oluşan tat eksikliğinin, uygun gıdaları analiz edebilme ve diyete bağlı kalmada engel oluşturduğu bulunmuştur (20). Diyabetli kadınlarda yapılan başka bir çalışmada ise komplikasyonları engellemek için motivasyon eksikliği ve ailenin diyet konusunda yetersiz desteği engeller arasında sayılmıştır (21). Diyabetle birlikte baş gösteren psikolojik sorunlarda bireyin hastalıkla baş etmesinde engel olarak gösterilmiştir (22). Yine yapılan çalışmalarda yaşam tarzını değiştirmek zorunda kalma, verilen diyet konusundaki bilgi eksikliği, diyetin ekonomik olarak yük getirmesi ve egzersiz için yeterli ekipmana sahip olmama engel olarak bildirilmiştir (23-25).

Ülkemizde Tip 2 diyabetli bireylerin karşılaştıkları engeller ile ilgili çalışmalar $(8,19,26)$ bulunmakla birlikte Tip 2 diyabetli bireylerin hastalık yönetiminde karşılaştıkları engellerin tüm boyutlarıyla daha geniş kapsamda ele alındığı sınırlı sayıda çalışma bulunmaktadır (8). Bu araştırma Tip 2 diyabetli bireylerin hastalık yönetiminde karşılaştıkları engelleri değerlendirmek ve bu engellere hastaların sosyodemografik ve hastalığa ilişkin özelliklerinin etkisini incelemek amacıyla yapılmıştır.

\section{GEREÇ VE YÖNTEMLER}

Araştırmamızın evrenini Atatürk Üniversitesi Sağlık Araştırma ve Uygulama Merkezinin Endokrinoloji klinik ve polikliniğine son bir y1l içerisinde başvurmuş ve en az 1 y1l önce tanı almış, 18 yaşından büyük Tip 2 diyabet hastaları oluşturmuştur. Hastane verilerine göre bu kriterlere uyan hasta sayısı 421'dir. Araştırmanın örneklemini ise, aynı birimde 07.10.2019- 30.11.2019 tarihleri arasında klinik ve poliklinikte bulunan, en az 1 yıl önce tanı almış, konuşma bozukluğu bulunmayan, psikiyatrik bozukluk tanısı almamış ve çalışmaya katılmaya gönüllü 120 hasta oluşturmuştur.

Çalışmanın örneklem büyüklüğünü belirlemek için, evreni bilinen örneklem yöntemiyle hesap yapılmış ve 96 kişilik örneklem sayısına ulaşılmıştır. Çalışmamız 120 hastayla tamamlanmıştır. Yapılan güç analizinde $\% 5$ yanılma düzeyinde testin gücü $\% 80$ düzeyindedir.

Veriler klinik ve polikilinikte bulunan Tip 2 diyabet hastalarından yüz yüze görüşme yapılarak toplamda 120 hastadan toplanmıştır. Araştırmacı tarafından hastalara araştırmanın amacı açıklanarak ve izin alınarak görüşmeler yapılmıştır. Görüşmeler yaklaşık 10-15 dakika sürmüştür. Boy, kilo, kan basıncı, bel ve kalça çevresi araştırmacı tarafından ölçülmüşsür. Hastanın labaratuvar bilgilerine ise hastane kayıtlarından ulaşılmıştır. Araştırma verileri, “Hasta Tanıtım Formu” ve "Diyabette Engeller Ölçeği (DEÖ)” kullanılarak elde edildi.

\section{Hasta Tanıtım Formu}

Hastaların sosyodemografik özelliklerini (cinsiyet, yaş, medeni durum, eğitim durumu, çalışma durumu, gelir durumu, sigara kullanma durumu ve alkol kullanma durumu), hastalık ile ilgili bilgilerini (tanı süresi, tedavi şekli, kan şekerine bakma durumu, tedaviye uyum algısı, diyete uyum algısı, egzersiz yapma durumu, doktora başvurma durumu, ailede diyabet olma durumu, diyabete bağlı komplikasyon oluşma durumu ve ek hastalık durumu) ve metabolik 
kontrol değişkenlerini (AKŞ, HbA1c, kan basıncı, BKİ, bel çevresi, kalça çevresi, kolesterol, trigliserid, HDL kolesterol ve LDL kolesterol değerleri) sorgulayan 22 soruluk bir formdur.

\section{Diyabette Engeller Ölçeği}

Hearnshaw ve ark. (27) tarafından 2007 yılında geliştirilmiş beşli likert tipinde bir ölçektir. Ülkemizde geçerliliği ve güvenilirliği 2014 yılında Kahraman ve ark. (13) tarafından yapılmıştır. Ölçek orjinalinde 78 sorudan oluşmaktadır. Geçerlilik ve güvenilirlik çalışmasının ardından toplumumuza uygun olmayan maddeler çıkarılmış ve 68 soru olarak çalışma tamamlanmıştır. İlaç engelleri, kendini izleme engelleri, bilgi ve inanç engelleri, tanıdaki engeller, sağlık profesyonelleri ile ilişkilerde engeller, yaşam tarzı değişikliği engelleri, diyabetle başa çıkma engelleri ve öneri ve destek almada engeller olmak üzere toplam 8 alt boyuttan oluşmaktadır. Ölçeğin puanlamasında, her boyutun ortalama puanı alınarak değerlendirme yapılmaktadır. Ölçek puanlamasında toplam puan hesaplanmamaktadır. Yanıt seçeneklerine, kesinlikle katılıyorum 2 puan, katılıyorum 1 puan, kararsızım 0 puan, katılmıyorum -1 puan, kesinlikle katılmıyorum -2 puan verilerek puanlanır. Negatif puanlar hastanın durumla ilgili zorluk yaşamadığını, pozitif puanlar ise hastanın zorluk yaşadığını göstermektedir. Bu şekilde elde edilen her boyut için elde edilen ortalama puan hastanın bu engelle ilgili yaşadığı zorluk derecesini yansıtmaktadır. Pozitif puan yaşanan engellerin artan şiddetini, negatif puan olumlu durumun düzeyini göstermektedir (27). Kahraman ve ark. (13) yaptıkları DEÖ’nün geçerlilik ve güvenilirlik çalışmasında Cronbach's Alpha değerlerini; İlaç Engelleri için 0.647, Kendini İzleme Engelleri için 0.659, Bilgi ve İnanç Engelleri için 0.846, Tanıdaki Engeller için 0.633, Sağlı Profesyonelleriyle İilişkilerdeki Engeller için 0.800, Yaşam Tarzı Engelleri için 0.715, Diyabetle Başa Çıkma Engelleri için 0.731, Öneri ve Destek Almada Engeller için 0.661 olarak bulmuştur. Ölçek uyarlamalarında güvenilirliğin önemli bir göstergesi olan Intraclass Correlation Coefficient ( ICC), bu çalışmada 0.86-0.97 arasında değişmekte olup 0.7-0.8 üzerinde bulunması DEÖ’nün değişmez biçimde aynı değerleri verdiği, tutarlı bir şekilde ölçek kavramlarını doğru ölçtüğünü göstermektedir. Çalışmamızda ise bu ölçek için Cronbach's Alpha değerleri; İlaç Engelleri için 0.752, Kendini İzleme Engelleri için 0.881, Bilgi ve İnanç Engelleri için 0.976 Tanıdaki Engeller için 0.842, Sağlık Profesyonelleri ile İlişkilerde Engeller için 0.960, Yaşam Tarzı Değişikliği Engelleri için 0.857 Diyabetle Başa Çıkma Engelleri için 0.846 Öneri ve Destek Almada Engeller için 0.803 bulunmuştur.

\section{İstatistiksel analiz}

Verilerin analizinde farklı istatistiksel analiz kullanılmış olup bu analizler bilgisayarda SPSS 22.00 istatistik paket programı ile yapılmıştır. Bu analizler; Frekans, yüzde, t Testi, Kruskal Wallis H testi, Dunnet T3 Post Hoc testi ve Mann Whitney U testidir.

Verilerin normal dağılıma uygunluğunu anlamak amacıyla yapılan analizler sonucu Skewness ve Kurtosis değerlerinin tümü -1.96 ile +1.96 aralığında bulunmuştur. Ayrıca incelenen histogram, Q-Q ve Detrendet grafiklerinin de normal dağılıma uygun olduğu görülmüştür. $\mathrm{Bu}$ bulgular verilerin normal dağılıma uyduğunu gösterdiğinden verilerin analizinde n sayısı 30'u aşan gruplarda parametrik analizler uygulanmıştır. 


\section{BULGULAR}

Hastaların \%61.7'si kadın, \% 38.3'ü erkek, \%11.7'si 50 yaş ve altı, \%33.3'ü 51-60 yaş, \%55'i 61 yaş ve üzeri, \%76.6'sı evlidir. Eğitim durumuna baktığımızda, \%45'inin ilkokul, \%4.2'sinin yükseköğretim mezunu olduğu görülmektedir. Hastaların \%88.3'ü çalışmıyor ve $\% 20$ 'sinin sigara kullandığı görülüyor.

Hastaların hastalığa ilişkin özellikleri incelendiğinde; \%62.5'inin 10 yıl ve daha fazla süredir diyabet hastası olduğu, \%50.8'inin oral antidiyabetik ve insülin tedavisini birlikte aldığ 1 , \%71.7'sinin kan şekeri ölçümü yaptığı tespit edilmiştir. Hastaların \%56.7' sinde diyabete bağlı komplikasyon geliştiği, \%35'inde Retinopati geliştiği ve \%65.8'inde diyabete eşlik eden ek hastalık öyküsü olduğu görülmüştür.

Hastaların AKŞ ortalaması 203.90 $\pm 80.31 \mathrm{mg} / \mathrm{dl}$, HbA1C ortalamas1 $10.43 \pm 2.63$ ' dür. Sistolik kan basıncı ortalaması $122.58 \pm 14.87 \mathrm{mmHg}$, diyastolik kan basinc1 ortalaması $74.08 \pm 8.25 \mathrm{mmHg}$, BKİ ortalamas1 29.89 $\pm 6.04 \mathrm{~kg} / \mathrm{cm} 2$, kolesterol ortalamas1 $202.08 \pm 53.35 \mathrm{mg} / \mathrm{dl}$, trigliserid ortalamas $197.16 \pm 108.05 \mathrm{mg} / \mathrm{dl}$, HDL ortalamas $144.53 \pm 12.62$ $\mathrm{mg} / \mathrm{dl}$, LDL ortalamas1 $126.11 \pm 39.22 \mathrm{mg} / \mathrm{dl}$ 'dir.

Hastaların DEÖ alt boyutlarına ait puan ortalamalarının dağılımı incelendiğinde en yüksek puan ortalaması $9.55 \pm 4.53$ ile Diyabetle Başa Çıkma Engelleri alt boyutuna aittir. En düşük puanı ise İlaç Kullanım Engelleri alt boyutu almıştır (-1.76 \pm 6.13$)$. Diğer alt boyutlarda ise Kendi Kendini İzleme Engelleri alt boyutu puan ortalamasının 2.38 \pm 4.61 , Bilgi ve İnanç Engelleri alt boyutu puan ortalamasının 6.22 \pm 7.83 , Tanıdaki Engeller alt boyutu puan ortalamasının .73 \pm 3.66 , Sağlık Profesyonelleri ile İlişkilerdeki Engeller alt boyutu puan ortalamasının - $.59 \pm 17.41$, Yaşam Tarzı Değişikliği Engelleri alt boyutu puan ortalamasının $8.69 \pm 9.58$, Öneri ve Destek Almada Engeller alt boyutu puan ortalamasının .37 \pm 5.84 olduğu sonucuna varılmıştır (Tablo 1).

Hastaların sosyodemografik özelliklerine göre DEÖ Alt Boyutlarından Aldıkları Puan Ortalamalarının Dağılımı Tablo 2'de verilmiştir.

Hastaların cinsiyetleri ile İlaç Kullanım Engelleri alt boyutu ortalama puanları açısından aralarındaki farklara ait KW değeri $\mathrm{p}<0.05$ önem düzeyinde anlamlı bulunmuştur. Tablo 2 incelendiğinde, erkeklerin negatif yönde ortalama puanlarının (-3.30 \pm 6.41$)$, kadınlara göre ($.80 \pm 5.79$ ) daha yüksek olduğu görülmektedir (Tablo 2).

Hastaların yaşlarına göre İlaç Kullanım Engelleri alt boyutu puan ortalamalarına ait KW değerinin istatistiksel olarak anlamlı fark oluşturduğu belirlenmiştir $(p<0.05)$. Farklılığın hangi gruptan kaynaklandığının bulmak maksadıyla Dunnet T3 Post Hoc testi uygulanmıştır. Dunnet T3 Post Hoc testi sonucunda, 50 yaş ve altındaki hastaların (1.00 \pm 5.99$), 61$ yaş ve üzerindeki $(-2.82 \pm 5.72)$ hastalara göre, İlaç Kullanım Engelleri alt boyutu ortalama puanlarının daha yüksek olduğu görülmüştür (Tablo 2).

Hastaların medeni durumuna göre, Öneri ve Destek Almada Engeller alt boyutu ortalama puanları açısından aralarındaki farklara ait KW değeri istatiksel olarak anlamlı bulunmuştur $(\mathrm{p}<0.05)$. Medeni duruma göre farklılığın hangi gruptan kaynaklandığını bulmak amacıyla Dunnet T3 Post Hoc testi uygulanmıştır. Dunnet T3 Post Hoc testi sonucunda, evli olan hastaların (1.12 \pm 5.62$)$, dul ve boşanmış $(-2.17 \pm 5.83)$ olan hastalara göre Öneri ve Destek Almada Engeller alt boyutu ortalama puanlarının daha fazla olduğu görülmüsstür (Tablo 2). 
Hastaların eğitim durumlarına göre Bilgi ve İnanç Engelleri alt boyutu ortalama puanları açısından aralarındaki farklara ait KW değerleri istatiksel olarak anlamlı bulunmuştur $(\mathrm{p}<0.05)$. Eğitim durumuna göre farklılığın hangi gruptan kaynaklandığını anlamak maksadıyla Dunnet T3 Post Hoc testi uygulanmıştır. Dunnet T3 Post Hoc testi sonucunda, eğitim durumu okuryazar olmayan (9.18 \pm 5.68$)$, okuryazar olan $(9.11 \pm 4.52)$ ve ilkokul mezunu (6.09 \pm 7.41$)$ olan hastaların, eğitim durumu ortaokul (-.67 \pm 10.97$)$ ve yükseköğretim $(-3.80 \pm 10.35)$ olan hastalara göre Bilgi ve İnanç Engelleri alt boyutu puan ortalamaları daha yüksek çıkmıştır. Sonuç olarak eğitim durumu okuryazar olmayan, okuryazar olan ve ilkokul mezunu olan hastaların eğitim durumu ortaokul ve yükseköğretim olan hastalara göre daha fazla Bilgi ve İnanç Engelleri yaşadıkları görülmektedir (Tablo 2).

Hastaların gelir durumlarına göre Diyabetle Başa Çıkma Engelleri alt boyutu ortalama puanları açısından aralarındaki farklara ait KW değeri $\mathrm{p}<0.05$ önem düzeyinde anlamlı bulunmuştur. Gelir durumuna göre farklılığın hangi gruptan kaynaklandığını anlamak maksadiyla Dunnet T3 Post Hoc testine başvurulmuştur. Test sonucunda, geliri giderinden az olan hastaların (10.86 \pm 3.02 ), geliri giderine eşit olan hastalara (8.22 \pm 5.26$)$ göre Diyabetle Başa Çıkma Engelleri alt boyutu ortalama puanları daha yüksek bulunmuştur. Geliri giderine göre az olan hastaların, geliri giderine eşit olan hastalara göre Diyabetle Başa Çıkma Engeli'ni daha fazla yaşadıkları görülmektedir (Tablo 2).

Hastaların hastalığa ilişkin özelliklerine göre DEÖ alt boyutlarından aldıkları puan ortalamalarının puan dağılımı açısından farklar Tablo 3 'te verilmiştir.

Tablo 1. Hastaların DEÖ Alt Boyutlarına Ait Puan Ortalamaları

\begin{tabular}{cccc}
\hline & Minimum & Maximum & $\bar{X} \pm$ S.s. \\
\hline İlaç Kullanım Engelleri Boyutu & -17 & 16 & $-1.76 \pm 6.13$ \\
Kendini İzleme Engeller Boyutu & -7 & 8 & $2.38 \pm 4.61$ \\
Bilgi ve İnanç Engelleri Boyutu & -16 & 16 & $6.22 \pm 7.83$ \\
Tanıdaki Engeller Boyutu & -6 & 6 & $.73 \pm 3.66$ \\
Sağlık Profesyonelleri ile İlişkilerde Engeller Boyutu & -33 & 54 & $-.59 \pm 17.41$ \\
Yaşam Tarzı Değişikliği Engelleri Boyutu & -14 & 24 & $8.69 \pm 9.58$ \\
Diyabetle Başa Çıkma Engelleri Boyutu & -7 & 14 & $9.55 \pm 4.53$ \\
Öneri ve Destek Almada Engeller Boyutu & -13 & 14 & $.37 \pm 5.84$ \\
\hline
\end{tabular}

Hastaların tanı süresine göre, Yaşam Tarzı Değişikliği Engelleri alt boyutu puan ortalamaları açısından aralarındaki farkları gösteren KW değeri istatiksel olarak anlamlı bulunmuştur $(\mathrm{p}<0.05)$. Tanı süresine göre farklılığın hangi grup kaynaklı olduğunu anlamak maksadiyla Dunnet T3 Post Hoc testine başvurulmuştur. Test sonucunda, tanı süresi 10 yıl ve

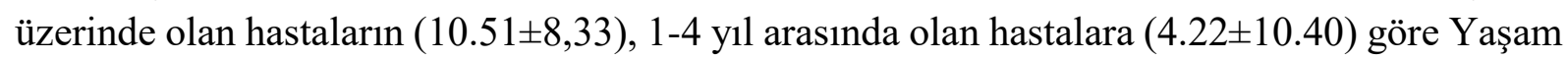
Tarzı Değissikliği Engelleri alt boyut puan ortalamasının daha yüksek olduğu görülmektedir (Tablo 3). 
Tablo 2. Hastaların Sosyodemografik Özelliklerine Göre DEÖ Alt Boyutlarından Aldıkları Puan Ortalamalarının Dağılımı

\begin{tabular}{|c|c|c|c|c|c|c|c|c|c|}
\hline & & $\begin{array}{c}\text { İlaç Kullanım } \\
\text { Engelleri }\end{array}$ & $\begin{array}{c}\text { Kendi Kendini } \\
\text { İzleme } \\
\text { Engeller }\end{array}$ & $\begin{array}{l}\text { Bilgi ve İnanç } \\
\text { Engelleri }\end{array}$ & $\begin{array}{l}\text { Tanıdaki } \\
\text { Engeller }\end{array}$ & $\begin{array}{c}\text { Sağlık } \\
\text { Profesyonelleri } \\
\text { ile İlişkilerdeki } \\
\text { Engeller }\end{array}$ & $\begin{array}{c}\text { Yaşam Tarzı } \\
\text { Değişikliği } \\
\text { Engelleri }\end{array}$ & $\begin{array}{l}\text { Diyabetle Başa } \\
\text { Çıkma Engelleri }\end{array}$ & $\begin{array}{l}\text { Öneri ve Destek } \\
\text { Almada Engeller }\end{array}$ \\
\hline & & $\bar{X} \pm$ S.s. & $\bar{X} \pm$ S.s. & $\bar{X} \pm$ S.s. & $\bar{X} \pm$ S.s. & $\bar{X} \pm$ S.s. & $\bar{X} \pm$ S.s. & $\bar{X} \pm$ S.s. & $\bar{X} \pm$ S.s. \\
\hline \multirow[t]{3}{*}{ Cinsiyet } & Kadın & $-.80 \pm 5.79$ & $2.73 \pm 4.45$ & $7.05 \pm 7.36$ & $1.12 \pm 3.62$ & $.88 \pm 17.94$ & $10.01 \pm 9.05$ & $9.41 \pm 4.19$ & $.68 \pm 5.91$ \\
\hline & Erkek & $-3.30 \pm 6.41$ & $1.80 \pm 4.86$ & $4.87 \pm 8.43$ & $.09 \pm 3.67$ & $-2.96 \pm 16.44$ & $6.57 \pm 10.12$ & $9.78 \pm 5.07$ & $-.13 \pm 5.75$ \\
\hline & TEST & $\begin{array}{c}t=2.213 \\
p=.029\end{array}$ & $\begin{array}{r}\mathrm{t}=1.070 \\
\mathrm{p}=.287\end{array}$ & $\begin{array}{r}\mathrm{t}=1.494 \\
\mathrm{p}=.138\end{array}$ & $\begin{array}{l}\mathrm{t}=1.514 \\
\mathrm{p}=.133\end{array}$ & $\begin{array}{c}\mathrm{t}=1.175 \\
\mathrm{p}=.242\end{array}$ & $\begin{array}{r}\mathrm{t}=1.939 \\
\mathrm{p}=.055\end{array}$ & $\begin{array}{c}\mathrm{t}=-.442 \\
\mathrm{p}=.659\end{array}$ & $\begin{array}{l}\mathrm{t}=.734 \\
\mathrm{p}=.464\end{array}$ \\
\hline \multirow[t]{5}{*}{ Yaş } & 50 yaş ve altı & $1.00 \pm 5.99$ & $.79 \pm 4.39$ & $4.93 \pm 8.74$ & $.93 \pm 3.83$ & $-1.50 \pm 18.06$ & $12.07 \pm 6.72$ & $10.07 \pm 3.63$ & $1.43 \pm 4.24$ \\
\hline & $51-60$ & $-.98 \pm 6.56$ & $3.55 \pm 4.33$ & $7.33 \pm 7.73$ & $.95 \pm 3.92$ & $1.13 \pm 19.48$ & $9.35 \pm 10.02$ & $10.15 \pm 3.34$ & $1.70 \pm 5.31$ \\
\hline & $\begin{array}{l}61 \text { yaş ve } \\
\text { üzeri }\end{array}$ & $-2.82 \pm 5.72$ & $2.00 \pm 4.72$ & $5.82 \pm 7.73$ & $.55 \pm 3.51$ & $-1.44 \pm 16.10$ & $7.58 \pm 9.73$ & $9.08 \pm 5.26$ & $-.67 \pm 6.28$ \\
\hline & TEST & $\begin{array}{c}\text { KW }=6.132 \\
p=.047\end{array}$ & $\begin{aligned} \mathrm{KW} & =4.158 \\
\mathrm{p} & =.125\end{aligned}$ & $\begin{aligned} \mathrm{KW} & =1.468 \\
\mathrm{p} & =.480\end{aligned}$ & $\begin{array}{c}\mathrm{KW}=.538 \\
\mathrm{p}=.764\end{array}$ & $\begin{array}{c}\mathrm{KW}=.004 \\
\mathrm{p}=.998\end{array}$ & $\begin{array}{c}\mathrm{KW}=2.966 \\
\mathrm{p}=.227\end{array}$ & $\begin{array}{c}\mathrm{KW}=.170 \\
\mathrm{p}=.919\end{array}$ & $\begin{array}{c}\mathrm{KW}=4.568 \\
\mathrm{p}=.102\end{array}$ \\
\hline & Fark & $\mathbf{1}>\mathbf{3}$ & - & - & - & - & - & - & - \\
\hline \multirow{5}{*}{$\begin{array}{l}\text { Medeni } \\
\text { Durum }\end{array}$} & Evli & $-1.48 \pm 6.36$ & $2.61 \pm 4.72$ & $6.23 \pm 7.73$ & $.57 \pm 3.64$ & $.05 \pm 16.74$ & $9.28 \pm 9.36$ & $9.98 \pm 4.18$ & $1.12 \pm 5.62$ \\
\hline & Bekar & $-4.20 \pm 3.42$ & $2.80 \pm 2.17$ & $5.80 \pm 12.66$ & $.80 \pm 4.87$ & $15.00 \pm 32.27$ & $6.40 \pm 9.42$ & $10.40 \pm 3.36$ & $-1.80 \pm 7.26$ \\
\hline & $\begin{array}{c}\text { Dul- } \\
\text { boşanmış }\end{array}$ & $-2.35 \pm 5.67$ & $1.35 \pm 4.56$ & $6.26 \pm 7.41$ & $1.35 \pm 3.58$ & $-6.57 \pm 14.02$ & $6.83 \pm 10.58$ & $7.65 \pm 5.66$ & $-2.17 \pm 5.83$ \\
\hline & TEST & $\begin{array}{c}\mathrm{KW}=1.245 \\
\mathrm{p}=.536\end{array}$ & $\begin{aligned} \mathrm{KW} & =1.525 \\
\mathrm{p} & =.466\end{aligned}$ & $\begin{array}{c}\mathrm{KW}=.093 \\
\mathrm{p}=.955\end{array}$ & $\begin{array}{c}\mathrm{KW}=.726 \\
\mathrm{p}=.695\end{array}$ & $\begin{array}{c}\mathrm{KW}=3.812 \\
\mathrm{p}=.149\end{array}$ & $\begin{aligned} \mathrm{KW} & =1.572 \\
\mathrm{p} & =.456\end{aligned}$ & $\begin{array}{c}\mathrm{KW}=4.333 \\
\mathrm{p}=.115\end{array}$ & $\begin{array}{c}\text { KW }=7.133 \\
p=.028\end{array}$ \\
\hline & Fark & - & - & - & - & - & - & - & $\mathbf{1}>\mathbf{3}$ \\
\hline
\end{tabular}


Tablo 2. Hastaların Sosyodemografik Özelliklerine Göre DEÖ Alt Boyutlarından Aldıkları Puan Ortalamalarının Dağılımı (devamı)

\begin{tabular}{|c|c|c|c|c|c|c|c|c|c|}
\hline & & $\begin{array}{c}\text { İlaç Kullanım } \\
\text { Engelleri }\end{array}$ & $\begin{array}{c}\text { Kendi Kendini } \\
\text { İzleme } \\
\text { Engeller }\end{array}$ & $\begin{array}{l}\text { Bilgi ve İnanç } \\
\text { Engelleri }\end{array}$ & $\begin{array}{l}\text { Tanıdaki } \\
\text { Engeller }\end{array}$ & $\begin{array}{c}\text { Sağlık } \\
\text { Profesyonelleri } \\
\text { ile İlişkilerdeki } \\
\text { Engeller }\end{array}$ & $\begin{array}{c}\text { Yaşam Tarzı } \\
\text { Değişikliği } \\
\text { Engelleri }\end{array}$ & $\begin{array}{c}\text { Diyabetle Başa } \\
\text { Çıkma } \\
\text { Engelleri }\end{array}$ & $\begin{array}{l}\text { Öneri ve Destek } \\
\text { Almada Engeller }\end{array}$ \\
\hline & & $\bar{X} \pm$ S.s. & $\bar{X} \pm$ S.s. & $\bar{X} \pm$ S.s. & $\bar{X} \pm$ S.s. & $\bar{X} \pm$ S.s. & $\bar{X} \pm$ S.s. & $\bar{X} \pm$ S.s. & $\bar{X} \pm$ S.s. \\
\hline \multirow{8}{*}{$\begin{array}{l}\text { Eğitim } \\
\text { Durumu }\end{array}$} & Okur yazar değil & $-1.79 \pm 6.03$ & $3.39 \pm 4.18$ & $9.18 \pm 5.68$ & $1.00 \pm 3.56$ & $4.54 \pm 20.13$ & $10.07 \pm 9.82$ & $10.1 \pm 3.97$ & $1.50 \pm 5.90$ \\
\hline & Okur yazar & $.56 \pm 6.88$ & $2.83 \pm 4.62$ & $9.11 \pm 4.52$ & $1.33 \pm 3.61$ & $-1.67 \pm 16.50$ & $9.28 \pm 8.57$ & $8.94 \pm 4.24$ & $-1.78 \pm 4.81$ \\
\hline & İlkokul & $-2.37 \pm 6.10$ & $2.61 \pm 4.57$ & $6.09 \pm 7.41$ & $.93 \pm 3.78$ & $-1.63 \pm 16.57$ & $9.11 \pm 10.03$ & $8.94 \pm 5.28$ & $.20 \pm 6.14$ \\
\hline & Ortaokul & $.22 \pm 4.71$ & $-.67 \pm 5.39$ & $-.67 \pm 10.97$ & $-1.89 \pm 3.22$ & $-4.00 \pm 15.97$ & $7.67 \pm 7.87$ & $9.78 \pm 2.91$ & $.56 \pm 6.13$ \\
\hline & Lise & $-3.00 \pm 5.48$ & $.00 \pm 5.02$ & $3.50 \pm 8.96$ & $.67 \pm 3.50$ & $.50 \pm 18.53$ & $1.33 \pm 11.34$ & $12.83 \pm 1.17$ & $2.33 \pm 6.31$ \\
\hline & Yükseköğretim & $-5.40 \pm 6.43$ & $.80 \pm 4.09$ & $-3.80 \pm 10.35$ & $-.40 \pm 3.51$ & $-9.40 \pm 14.79$ & $5.00 \pm 5.57$ & $10.80 \pm 3.49$ & $.80 \pm 4.49$ \\
\hline & TEST & $\begin{array}{c}\mathrm{KW}=5.670 \\
\mathrm{p}=.340\end{array}$ & $\begin{array}{c}\mathrm{KW}=7.462 \\
\mathrm{p}=.188\end{array}$ & $\begin{array}{c}\mathrm{KW}=\mathbf{1 6 . 2 4 0} \\
\mathrm{p}=.006\end{array}$ & $\begin{array}{c}\mathrm{KW}=5.937 \\
\mathrm{p}=.312\end{array}$ & $\begin{array}{c}\mathrm{KW}=3.467 \\
\mathrm{p}=.628\end{array}$ & $\begin{array}{c}\mathrm{KW}=5.656 \\
\mathrm{p}=.341\end{array}$ & $\begin{array}{c}\mathrm{KW}=7.550 \\
\mathrm{p}=.183\end{array}$ & $\begin{aligned} \mathrm{KW} & =3.932 \\
\mathrm{p} & =.559\end{aligned}$ \\
\hline & Fark & - & - & $1-2-3>4-6$ & - & - & - & - & - \\
\hline \multirow{5}{*}{$\begin{array}{c}\text { Gelir } \\
\text { durumu }\end{array}$} & Gelir giderden az & $-1.69 \pm 6.38$ & $2.43 \pm 4.62$ & $7.38 \pm 7.73$ & $1.43 \pm 3.64$ & $.05 \pm 18.75$ & $10.02 \pm 8.24$ & $10.86 \pm 3.02$ & $1.43 \pm 6.68$ \\
\hline & Gelir gidere eşit & $-2.00 \pm 5.38$ & $2.85 \pm 4.47$ & $6.95 \pm 6.76$ & $.49 \pm 3.63$ & $.85 \pm 17,09$ & $7.24 \pm 10.77$ & $8.22 \pm 5.26$ & $-.85 \pm 5.49$ \\
\hline & Gelir giderden fazla & $-1.30 \pm 7.50$ & $1.13 \pm 4.89$ & $2.35 \pm 9.40$ & $.00 \pm 3.71$ & $-5.22 \pm 15.47$ & $9.74 \pm 8.70$ & $10.35 \pm 4.20$ & $1.35 \pm 4.51$ \\
\hline & TEST & $\begin{array}{c}\mathrm{KW}=.020 \\
\mathrm{p}=.990\end{array}$ & $\begin{aligned} \mathrm{KW} & =2.291 \\
\mathrm{p} & =.318\end{aligned}$ & $\begin{aligned} \mathrm{KW} & =5.529 \\
\mathrm{p} & =.063\end{aligned}$ & $\begin{array}{c}\mathrm{KW}=2.601 \\
\mathrm{p}=.272\end{array}$ & $\begin{array}{c}\mathrm{KW}=1.603 \\
\mathrm{p}=.449\end{array}$ & $\begin{array}{c}\mathrm{KW}=1.384 \\
\mathrm{p}=.501\end{array}$ & $\begin{array}{c}\mathrm{KW}=\mathbf{9 . 4 7 0} \\
\mathbf{p}=.009\end{array}$ & $\begin{array}{c}\mathrm{KW}=4.650 \\
\mathrm{p}=.098\end{array}$ \\
\hline & Fark & - & - & - & - & - & - & $1>2$ & - \\
\hline
\end{tabular}


Tablo 3. Hastaların Hastalığa İlişkin Özelliklerine Göre DEÖ Alt Boyutlarından Aldıkları Puan Ortalamalarının Dağılımı

\begin{tabular}{|c|c|c|c|c|c|c|c|c|c|}
\hline & & $\begin{array}{l}\text { İlaç Kullanım } \\
\text { Engelleri }\end{array}$ & $\begin{array}{c}\text { Kendi Kendini } \\
\text { İzleme } \\
\text { Engeller }\end{array}$ & $\begin{array}{l}\text { Bilgi ve İnanç } \\
\text { Engelleri }\end{array}$ & $\begin{array}{l}\text { Tanıdaki } \\
\text { Engeller }\end{array}$ & $\begin{array}{c}\text { Sağlık } \\
\text { Profesyonelleri } \\
\text { ile İlişkilerdeki } \\
\text { Engeller } \\
\end{array}$ & $\begin{array}{c}\text { Yaşam Tarzı } \\
\text { Değişikliği } \\
\text { Engelleri }\end{array}$ & $\begin{array}{c}\text { Diyabetle Başa } \\
\text { Çıkma } \\
\text { Engelleri }\end{array}$ & $\begin{array}{l}\text { Öneri ve } \\
\text { Destek } \\
\text { Almada } \\
\text { Engeller } \\
\end{array}$ \\
\hline & & $\bar{X} \pm$ S.s. & $\bar{X} \pm$ S.s. & $\bar{X} \pm$ S.s. & $\bar{X} \pm$ S.s. & $\bar{X} \pm$ S.s. & $\bar{X} \pm$ S.s. & $\bar{X} \pm$ S.s. & $\bar{X} \pm$ S.s. \\
\hline \multirow[t]{5}{*}{ Tanı süresi } & 1-4 yıl arası & $-3.61 \pm 5.81$ & $3.52 \pm 4.23$ & $4.87 \pm 9.22$ & $.22 \pm 3.72$ & $-1.52 \pm 17.09$ & $4.22 \pm 10.40$ & $7.48 \pm 6.68$ & $-.48 \pm 5.97$ \\
\hline & $5-9$ yıl arası & $-2.23 \pm 6.75$ & $3.59 \pm 4.38$ & $8.50 \pm 6.72$ & $.18 \pm 3.86$ & $-3.27 \pm 16.13$ & $7.18 \pm 11.24$ & $8.36 \pm 5.42$ & $.14 \pm 5.56$ \\
\hline & 10 yıl ve üzeri & $-1.05 \pm 5.99$ & $1.67 \pm 4.70$ & $5.96 \pm 7.63$ & $1.04 \pm 3.60$ & $.48 \pm 17.98$ & $10.51 \pm 8.33$ & $10.53 \pm 2.94$ & $.69 \pm 5.93$ \\
\hline & TEST & $\begin{array}{c}\mathrm{KW}=2.681 \\
\mathrm{p}=.262\end{array}$ & $\begin{aligned} \mathrm{KW} & =4.422 \\
\mathrm{p} & =.110\end{aligned}$ & $\begin{aligned} \mathrm{KW} & =3.584 \\
\mathrm{p} & =.167\end{aligned}$ & $\begin{array}{c}\mathrm{KW}=1.224 \\
\mathrm{p}=.542\end{array}$ & $\begin{array}{c}\mathrm{KW}=.377 \\
\mathrm{p}=.828\end{array}$ & $\begin{array}{c}\mathrm{KW}=7.663 \\
p=.022\end{array}$ & $\begin{array}{c}\mathrm{KW}=4.047 \\
\mathrm{p}=.132\end{array}$ & $\begin{aligned} \mathrm{KW} & =1.001 \\
\mathrm{p} & =.606\end{aligned}$ \\
\hline & Fark & - & - & - & - & - & $3>1$ & - & - \\
\hline \multirow{6}{*}{$\begin{array}{l}\text { Diyabet } \\
\text { tedavi tipi }\end{array}$} & Diyet & $-10.00 \pm 1.41$ & $4.50 \pm 0.71$ & $.50 \pm 21.92$ & $3.00 \pm 4.24$ & $11.00 \pm 60.81$ & $4.00 \pm 15.56$ & $5.00 \pm 8.49$ & $-1.00 \pm 7.07$ \\
\hline & Oral antidiyabetik & $-2.38 \pm 6.23$ & $3.54 \pm 4.21$ & $5.79 \pm 9.33$ & $.33 \pm 3.36$ & $-1.13 \pm 16.72$ & $7.25 \pm 11.10$ & $8.04 \pm 6.00$ & $.00 \pm 5.62$ \\
\hline & İnsülin & $-2.33 \pm 5.52$ & $1.79 \pm 4.66$ & $6.58 \pm 5.85$ & $1.06 \pm 3.88$ & $-3.00 \pm 15.54$ & $7.55 \pm 7.57$ & $9.48 \pm 4.87$ & $-2.03 \pm 6.28$ \\
\hline & $\begin{array}{c}\text { Oral } \\
\text { antidiyabetik }+ \text { insülin }\end{array}$ & $-.93 \pm 6.34$ & $2.16 \pm 4.78$ & $6.38 \pm 7.78$ & $.62 \pm 3.69$ & $.54 \pm 17.16$ & $10.03 \pm 9.81$ & $10.33 \pm 3.29$ & $1.85 \pm 5.30$ \\
\hline & Test & $\begin{array}{c}\mathrm{KW}=6.947 \\
\mathrm{p}=.074\end{array}$ & $\begin{aligned} \mathrm{KW} & =2.178 \\
\mathrm{p} & =.536\end{aligned}$ & $\begin{array}{c}\mathrm{KW}=.433 \\
\mathrm{p}=.933\end{array}$ & $\begin{array}{c}\mathrm{KW}=1.341 \\
\mathrm{p}=.719\end{array}$ & $\begin{array}{c}\mathrm{KW}=.292 \\
\mathrm{p}=.962\end{array}$ & $\begin{aligned} \mathrm{KW} & =4.570 \\
\mathrm{p} & =.206\end{aligned}$ & $\begin{aligned} \mathrm{KW} & =2.666 \\
\mathrm{p} & =.446\end{aligned}$ & $\begin{aligned} & K W=9.103 \\
& p=.028\end{aligned}$ \\
\hline & Fark & - & - & - & - & - & - & - & $4>3$ \\
\hline \multirow{5}{*}{$\begin{array}{c}\text { Şu anki } \\
\text { diyabet } \\
\text { tedavisine } \\
\text { uyum algısı }\end{array}$} & İyi & $-5.14 \pm 6.74$ & $1.45 \pm 4.60$ & $2.05 \pm 10.86$ & $.59 \pm 4.09$ & $-9.36 \pm 15.05$ & $4.68 \pm 11.16$ & $6.45 \pm 7.57$ & $-1.77 \pm 7.65$ \\
\hline & Orta & $-.54 \pm 5.81$ & $3.25 \pm 4.40$ & $7.40 \pm 6.69$ & $.98 \pm 3.71$ & $.17 \pm 18.62$ & $9.17 \pm 9.35$ & $9.85 \pm 3.49$ & $.75 \pm 5.74$ \\
\hline & Kötü & $-1.52 \pm 5.71$ & $1.83 \pm 4.78$ & $6.87 \pm 6.75$ & $.50 \pm 3.44$ & $2.74 \pm 15.92$ & $10.07 \pm 8.69$ & $10.70 \pm 2.75$ & $.96 \pm 4.78$ \\
\hline & Test & $\begin{array}{c}\mathrm{KW}=\mathbf{1 0 . 8 3 3} \\
\mathrm{p}=.004\end{array}$ & $\begin{array}{c}\mathrm{KW}=2.813 \\
\mathrm{p}=.245\end{array}$ & $\begin{array}{c}\mathrm{KW}=3.555 \\
\mathrm{p}=.169\end{array}$ & $\begin{array}{c}\mathrm{KW}=.558 \\
\mathrm{p}=.756\end{array}$ & $\begin{array}{c}K W=7.177 \\
p=.028\end{array}$ & $\begin{array}{c}\mathrm{KW}=3.195 \\
\mathrm{p}=.202\end{array}$ & $\begin{array}{c}\mathrm{KW}=3.285 \\
\mathrm{p}=.194\end{array}$ & $\begin{array}{c}\mathrm{KW}=3.883 \\
\mathrm{p}=.143\end{array}$ \\
\hline & Fark & $2-3>1$ & - & - & - & $2-3>1$ & - & - & - \\
\hline
\end{tabular}


Tablo 3. Hastaların Hastalığa İlişkin Özelliklerine Göre DEÖ Alt Boyutlarından Aldıkları Puan Ortalamalarının Dağılımı (devamı)

\begin{tabular}{|c|c|c|c|c|c|c|c|c|c|}
\hline & & $\begin{array}{c}\text { İlaç Kullanım } \\
\text { Engelleri }\end{array}$ & $\begin{array}{c}\text { Kendi Kendini } \\
\text { İzleme Engeller }\end{array}$ & $\begin{array}{l}\text { Bilgi ve } \\
\text { İnanç } \\
\text { Engelleri }\end{array}$ & $\begin{array}{l}\text { Tanıdaki } \\
\text { Engeller }\end{array}$ & $\begin{array}{c}\text { Sağlık } \\
\text { Profesyonelleri ile } \\
\text { İlişkilerdeki } \\
\text { Engeller }\end{array}$ & $\begin{array}{c}\text { Yaşam Tarzı } \\
\text { Değişikliği } \\
\text { Engelleri }\end{array}$ & $\begin{array}{c}\text { Diyabetle Başa } \\
\text { Çıkma } \\
\text { Engelleri }\end{array}$ & $\begin{array}{c}\text { Öneri ve } \\
\text { Destek } \\
\text { Almada } \\
\text { Engeller }\end{array}$ \\
\hline & & $\bar{X} \pm$ S.s. & $\bar{X} \pm$ S.s. & $\bar{X} \pm$ S.s. & $\bar{X} \pm$ S.s. & $\bar{X} \pm$ S.s. & $\bar{X} \pm$ S.s. & $\bar{X} \pm$ S.s. & $\bar{X} \pm$ S.s. \\
\hline \multirow{4}{*}{$\begin{array}{l}\text { Kan şekeri ölçümü } \\
\text { yapılma durumu }\end{array}$} & Evet & $-1.72 \pm 5.95$ & $1.28 \pm 4.31$ & $5.23 \pm 7.95$ & $.67 \pm 3.50$ & $-.47 \pm 17.86$ & $8.67 \pm 8.82$ & $9.31 \pm 4.68$ & $.26 \pm 5.88$ \\
\hline & Hayır & $-1.85 \pm 6.67$ & $5.15 \pm 4.21$ & $8.71 \pm 7.02$ & $.85 \pm 4.09$ & $-.91 \pm 16.48$ & $8.74 \pm 11.42$ & $10.15 \pm 4.13$ & $.65 \pm 5.80$ \\
\hline & Test & $\mathrm{t}=.106$ & $t=-4.457$ & $\mathrm{t}=-2.227$ & $\mathrm{t}=-.240$ & $\mathrm{t}=.126$ & $\mathrm{t}=-.031$ & $\mathrm{t}=-.908$ & $\mathrm{t}=-.330$ \\
\hline & & $\mathrm{p}=.916$ & $p=.000$ & $\mathrm{p}=.028$ & $\mathrm{p}=.811$ & $\mathrm{p}=.900$ & $\mathrm{p}=.975$ & $\mathrm{p}=.366$ & $\mathrm{p}=.742$ \\
\hline \multirow[t]{6}{*}{ Diyete uyum algısı } & İyi & $-3.88 \pm 5.94$ & $1.65 \pm 4.21$ & $5.24 \pm 11.09$ & $.71 \pm 3.80$ & $-6.35 \pm 17.92$ & $3.65 \pm 8.95$ & $6.06 \pm 6.78$ & $-1.12 \pm 5.56$ \\
\hline & Orta & $-1.46 \pm 5.69$ & $2.75 \pm 4.71$ & $6.21 \pm 7.06$ & $1.00 \pm 3.65$ & $-1.38 \pm 17.82$ & $6.96 \pm 10.61$ & $9.44 \pm 4.48$ & $-.69 \pm 6.20$ \\
\hline & Kötü & $-1.35 \pm 6.59$ & $2.24 \pm 4.68$ & $6.55 \pm 7.43$ & $.45 \pm 3.67$ & $2.14 \pm 16.59$ & $12.14 \pm 7.36$ & $10.82 \pm 2.79$ & $1.94 \pm 5.26$ \\
\hline & Test & $\mathrm{KW}=2.377$ & $\mathrm{KW}=.891$ & $\mathrm{KW}=.485$ & $\mathrm{KW}=.606$ & $\mathrm{KW}=3.156$ & $\mathrm{KW}=12.454$ & KW=9.437 & KW=6.790 \\
\hline & & $\mathrm{p}=.305$ & $\mathrm{p}=.641$ & $\mathrm{p}=.785$ & $\mathrm{p}=.739$ & $\mathrm{p}=.206$ & $p=.002$ & $p=.009$ & $p=.034$ \\
\hline & Fark & - & - & - & - & - & $3>1-2$ & $2-3>1$ & $3>2$ \\
\hline \multirow{4}{*}{$\begin{array}{c}\text { Egzersiz yapma } \\
\text { durumu }\end{array}$} & Evet & $-2.63 \pm 5.92$ & $2.60 \pm 4.39$ & $4.85 \pm 8.86$ & $.60 \pm 3.71$ & $-1.77 \pm 19.05$ & $2.65 \pm 9.74$ & $9.04 \pm 5.40$ & $.13 \pm 6.49$ \\
\hline & Hayır & $-1.18 \pm 6.25$ & $2.22 \pm 4.78$ & $7.13 \pm 6.97$ & $.81 \pm 3.65$ & $.19 \pm 16.32$ & $12.72 \pm 7.06$ & $9.89 \pm 3.84$ & $.53 \pm 5.40$ \\
\hline & Test & $\mathrm{t}=-1.267$ & $\mathrm{t}=.443$ & $\mathrm{t}=-1.494$ & $\mathrm{t}=-.294$ & $t=-.604$ & $t=-6.167$ & $\mathrm{t}=-1.004$ & $\mathrm{t}=-.369$ \\
\hline & & $\mathrm{p}=.208$ & $\mathrm{p}=.659$ & $\mathrm{p}=.139$ & $\mathrm{p}=.769$ & $\mathrm{p}=.547$ & $p=.000$ & $\mathrm{p}=.317$ & $\mathrm{p}=.713$ \\
\hline
\end{tabular}


Tablo 3. Hastaların Hastalı̆̆a İlişkin Özelliklerine Göre DEÖ Alt Boyutlarından Aldıkları Puan Ortalamalarının Dağılımı (devamı)

\begin{tabular}{|c|c|c|c|c|c|c|c|c|c|}
\hline & & $\begin{array}{c}\text { İlaç Kullanım } \\
\text { Engelleri }\end{array}$ & $\begin{array}{l}\text { Kendi Kendini } \\
\text { İzleme Engeller }\end{array}$ & $\begin{array}{l}\text { Bilgi ve } \\
\text { İnanç } \\
\text { Engelleri }\end{array}$ & $\begin{array}{l}\text { Tanıdaki } \\
\text { Engeller }\end{array}$ & $\begin{array}{c}\text { Sağlık } \\
\text { Profesyonelleri ile } \\
\text { İlişkilerdeki } \\
\text { Engeller }\end{array}$ & $\begin{array}{l}\text { Yaşam Tarzı } \\
\text { Değişikliği } \\
\text { Engelleri }\end{array}$ & $\begin{array}{c}\text { Diyabetle Başa } \\
\text { Çıkma } \\
\text { Engelleri }\end{array}$ & $\begin{array}{l}\text { Öneri ve } \\
\text { Destek } \\
\text { Almada } \\
\text { Engeller }\end{array}$ \\
\hline & & $\bar{X} \pm$ S.s. & $\bar{X} \pm$ S.s. & $\bar{X} \pm$ S.s. & $\bar{X} \pm$ S.s. & $\bar{X} \pm$ S.s. & $\bar{X} \pm$ S.s. & $\bar{X} \pm$ S.s. & $\bar{X} \pm$ S.s. \\
\hline \multirow{4}{*}{$\begin{array}{l}\text { Diyabete bağlı } \\
\text { gelişen } \\
\text { komplikasyon } \\
\text { durumu }\end{array}$} & Evet & $-1.29 \pm 6.04$ & $2.03 \pm 4.81$ & $7.63 \pm 7.17$ & $.76 \pm 3.83$ & $.37 \pm 17.81$ & $9.69 \pm 8.91$ & $10.38 \pm 3.69$ & $.75 \pm 6.02$ \\
\hline & Hayır & $-2.37 \pm 6.27$ & $2.83 \pm 4.34$ & $4.37 \pm 8.32$ & $.67 \pm 3.46$ & $-1.85 \pm 16.96$ & $7.38 \pm 10.34$ & $8.46 \pm 5.28$ & $-.13 \pm 5.61$ \\
\hline & TEST & $\mathrm{t}=.948$ & $\mathrm{t}=-.938$ & $t=2.261$ & $\mathrm{t}=.135$ & $\mathrm{t}=.689$ & $\mathrm{t}=1.311$ & $\mathrm{t}=2.240$ & $\mathrm{t}=.821$ \\
\hline & & $\mathrm{p}=.345$ & $\mathrm{p}=.350$ & $p=.026$ & $\mathrm{p}=.893$ & $\mathrm{p}=.492$ & $\mathrm{p}=.192$ & $p=.028$ & $\mathrm{p}=.413$ \\
\hline Ek hastalık & Evet & $-2.24 \pm 6.14$ & $2.23 \pm 4.84$ & $6.84 \pm 7.35$ & $.35 \pm 3.77$ & $-.56 \pm 17.34$ & $10.00 \pm 8.75$ & $10.10 \pm 4.07$ & $.86 \pm 6.04$ \\
\hline \multirow[t]{3}{*}{ olma durumu } & Hayır & $-.83 \pm 6.09$ & $2.66 \pm 4.17$ & $5.02 \pm 8.64$ & $1.44 \pm 3.38$ & $-.66 \pm 17.76$ & $6.17 \pm 10.67$ & $8.49 \pm 5.19$ & $-.59 \pm 5.38$ \\
\hline & TEST & $\mathrm{t}=-1.198$ & $\mathrm{t}=-.484$ & $\mathrm{t}=1.205$ & $\mathrm{t}=-1.549$ & $\mathrm{t}=.030$ & $t=2.106$ & $\mathrm{t}=1.732$ & $\mathrm{t}=1.291$ \\
\hline & & $\mathrm{p}=.233$ & $\mathrm{p}=.629$ & $\mathrm{p}=.231$ & $\mathrm{p}=.124$ & $\mathrm{p}=.976$ & $p=.037$ & $\mathrm{p}=.088$ & $\mathrm{p}=.199$ \\
\hline
\end{tabular}


Hastaların diyabet tedavi tipine göre, Öneri ve Destek Almada Engeller alt boyutu puan ortalamaları açısından aralarındaki farklara ait KW değeri anlamlı bulunmuştur $(\mathrm{p}<0.05)$. Diyabet tedavi tipine göre farklılığın hangi gruptan kaynaklandığını bulmak maksadıyla Dunnet T3 Post Hoc testi uygulanmıştır. OAD+insülin tedavisi alan hastaların (1.85 \pm 5.30$)$, sadece insülin tedavisi $(.00 \pm 5.62)$ alan hastalara göre daha fazla öneri ve destek almada engel yaşadıkları belirlenmiştir (Tablo 3).

Hastaların diyabet tedavisine uyum algısına göre, İlaç Kullanım Engelleri ve Sağlık Profesyonelleri ile İlişkilerdeki Engeller alt boyut ortalama puanlarına ait KW değerinin istatistiksel olarak anlamlı fark oluşturduğu belirlenmiştir $(\mathrm{p}<0.05)$. Diyabet tedavisine uyum algısına göre farkın hangi gruptan kaynaklandığını anlamak amacıyla Dunnet T3 Post Hoc testi uygulanmıştır. Test sonucunda, diyabet tedavisine uyumunu orta ve kötü olarak tanımlayan hastaların, diyabet tedavisine uyum algısı iyi olan hastalara göre ilaç kullanımında ve sağlık profesyonelleriyle ilişkilerde daha fazla engel yaşadıkları görülmektedir (Tablo 3).

Hastaların kan şekeri ölçümü yapma durumuna göre, Kendi Kendini İzleme Engelleri alt boyutu ortalama puanları açısından aralarındaki farklara ait $\mathrm{t}$ değeri istatiksel olarak anlamlı bulunmuştur. Tablonun incelenmesine devam edildiğinde, kan şekeri ölçümü yapmayan hastaların (5.15 \pm 4.21$)$, kan şekeri ölçümü yapan hastalara (1.28 \pm 4.31$)$ göre daha fazla kendi kendini izleme engeli yaşadıkları görülmektedir (Tablo 3) $(\mathrm{p}<0.05)$.

Hastaların diyete uyum algısına göre, Yaşam Tarzı Değişikliği Engelleri, Diyabetle Başa Çıkma Engelleri ve Öneri ve Destek Almada Engeller alt boyutları ortalama puanlarına ait KW değerinin istatistiksel olarak anlamlı fark oluşturduğu belirlenmiştir $(p<0.05)$. Diyete uyum algısına göre farklılığın hangi gruptan kaynaklandığını bulmak maksadıyla Dunnet T3 Post Hoc testi uygulanmıştır. Bu test sonucunda, diyete uyumunu kötü olarak belirten hastaların, diyete uyumunu iyi ve orta olarak belirten hastalara göre daha fazla yaşam tarzını değiştirmekte engel yaşadıkları görülmektedir. Ayrıca diyete uyum algısını orta ve kötü olarak belirten hastalar diyete uyumunu iyi olarak belirten hastalara göre daha fazla diyabetle başa çıkma engeli yaşıyor. Diyete uyumunu kötü olarak belirten hastalar diyete uyumu orta olan hastalara göre daha fazla öneri ve destek almada engel yaşamaktadır (Tablo 3).

Hastaların egzersiz yapma durumuna göre, Yaşam Tarzı Değişikliği Engelleri alt boyutu puan ortalamaları açısından aralarındaki farklara ait $t$ değeri anlamlı bulunmuştur $(p<0.05)$. Tablonun incelenmesine devam edildiğinde, egzersiz yapmayan hastaların (12.72 \pm 7.06 ), egzersiz yapan hastalara (2.65 \pm 9.74$)$ göre yaşam tarzını değiştirmekte daha fazla engel yaşadıkları görülmektedir (Tablo 3).

Hastaların diyabete bağlı komplikasyon gelişme durumuna göre, Bilgi ve İnanç Engelleri ve Diyabetle Başa Çıkma Engelleri alt boyut puan ortalamalarına ait KW değerinin istatistiksel olarak anlamlı fark oluşturduğu belirlenmiştir $(p<0.05)$. Tablonun incelenmesine devam edildiğinde, diyabete bağlı komplikasyon gelişen hastaların, komplikasyon gelişmeyen hastalara göre daha fazla diyabetle başa çıkma ve bilgi ve inanç engeli yaşadıkları görülmektedir (Tablo 3).

Hastaların ek bir hastalığının olma durumuna göre, Yaşam Tarzı Değişikliği Engeller alt boyutu puan ortalamaları açısından aralarındaki farklara ait $t$ değeri anlamlı bulunmuştur $(p<0.05)$. Tablo incelendiğinde, ek bir hastalığı olan hastaların $(10.00 \pm 8.75)$, ek hastalığ olmayan $(6.17 \pm 10.67)$ hastalara göre yaşam tarzı değişikliğinde daha fazla engel yaşadıkları görülmektedir (Tablo 3). 


\section{TARTIŞMA}

$\mathrm{Bu}$ bölümde çalışmamızdan elde edilen veriler konuyla ilgili literatür doğrultusunda tartışılmıştır.

Çalışmamızda metabolik kontrol değerlerinden AKŞ, HbA1c, HDL kolesterol, LDL kolesterol, trigliserid ve BKİ ortalamaları normal değerlerin üzerindedir. Bu sonuçlar hastaların metabolik kontrollerinin kötü olduğunu işaret etmektedir.

$\mathrm{Bu}$ çalışmada hastaların diyabetle başa çıkma engelleri alt boyutu en yüksek puan ortalamasına sahiptir (Tablo 1). Bu boyutta hastaların hastalığa karşı tutum ve bakış açısı sorgulanmaktadır. Hastaların hastalığa karşı olumsuz bir tutum sergiledikleri görülmektedir. Yurt dışında ve ülkemizde yapılan birçok çalışmada hastaların hastalığa karşı negatif bir tutum sergiledikleri bulunmuştur (8,26,28-30). Hastalıkla ilgili olumlu bir bakış açısı olanlar diyabet bakımlarında daha aktif ve kontrol duygusu daha yüksek bireyler olmaktadır (24). Bu sonuç, diyabet hastalığının her evresinde büyük bir özveri gerektirmesi ve bireye yüklenen sorumlulukların oldukça fazla olmasıyla açıklanabilir.

Bu çalışmada diyabet yönetiminde karşılaşılan engellerde en düşük puan ortalaması ilaç kullanım engelleridir (-1.76 \pm 6.13 ) (Tablo 1). Bu puan ortalaması hastaların bu boyutta engel yaşamadıklarını ifade etmektedir. Bu çalışmayla uyumlu olarak Üren ve Yılmaz Karabulutlu'nun (8), Özcan (26) ve Kara ve Çınar'ın (28) yaptıkları çalışmalarda da hastaların insülin ve ilaç dozlarıyla ilgili tutumlarını ölçen tedavi engelleri alt boyutu en düşük puan ortalaması olarak belirlenmiştir. Boccuzzi ve ark. (32) yaptıkları bir çalışmada tip 2 diyabet hastalarının 12 aylık oral antidiyabetik ilaç kullanım uyumlarını yaklaşık olarak \%79 bulmuşlardır. Diğer çalışmalarda da tedavi engelleri boyutu en düşük puan olarak saptanmıştır (33-34). Diyabet hastalarının baş etmesi gereken birçok sorun vardır. Ancak ilaç kullanımına, yaşam tarzını değiştirmek gibi daha büyük bir çaba isteyen durumlara göre uyum sağlanması daha kolaydır. Bu nedenle bu alt boyutun en az engel yaşanan durum olduğu düşünülmektedir.

Hastaların sosyodemografik özelliklerine göre cinsiyet, yaş, medeni durum, eğitim durumu ve gelir durumunda anlamlı farklılıklar görülmektedir. Kadın hastaların erkek hastalara göre ilaç kullanımında daha çok engele sahip oldukları görülmektedir ( $\mathrm{p}<0.05)$ (Tablo 2). İlaç kullanım engelleri alt boyutunda ilaç etkinliğine inanma, ilacın doğru bir şekilde alınıp alınmama durumu ve insülin kullanımı konusundaki tutumlar sorgulanmaktadır. Çalışmamızda bireylerin \%50.8'i OAD+insülin kullanmaktadır. İnsülin kullanımı gün içerisinde özellikle beslenme konusunda belli bir düzen gerektirmektedir. Ancak kadınların toplumda anne olmak, eş olmak, ev kadını olmak gibi sorumluluk gerektiren oldukça zor rollerinin olması (35) ve bu rollerden kaynaklı istenilen düzeni kuramamaları bu durumu açıklayabilir.

Hastaların yaşı ile ilaç kullanım engelleri alt boyutunda anlamlı bir farklılık görülmektedir. 50 yaş ve altında olan hastaların, 61 yaş ve üzerinde olan hastalara göre, ilaç kullanımında daha çok engel yaşadıkları sonucu çıkmıştır $(\mathrm{p}<0.05)$ (Tablo 2). Bu konudaki bulgular literatürde farklılık göstermektedir. Bir çalışmada yaşla birlikte ilaca bağlılığın daha çok arttığ bildirilmiştir (36). Bazı çalışmalarda ise yaş faktörünün tedaviye uyumu etkilemediği belirlenmiştir (37,38). Bir üniversite hastanesinde tedavi gören diyabetik yaşlıların ilaç uyumlarını araştıran bir çalışmada hastaların ilaç uyumu \% 61.1 olarak bulunmuştur (39). Bu durum genç bireylerin daha sosyal ve aktif bir hayata sahip olmaları ve bu hayatın getirdiği 
dinamik yapıdan dolayı özellikle insülin kullanımının getirdiği belli bir düzene tabi olmakta zorlanmaları ile açıklanabilir.

Hastaların medeni durumlarına göre öneri ve destek almada engeller alt boyut puan ortalaması arasında anlamlı bir fark bulunmuştur $(\mathrm{p}<0.05)$ (Tablo 2). Evli olan hastaların dul ve boşanmış olan hastalara oranla daha fazla öneri ve destek alma engeli yaşadıkları sonucuna ulaşılmıştır. Diyabetik ayak gelişen hastalarla yapılan bir çalışmada medeni durumun algılanan sosyal destekle ilişkisi bulunamamıştır (40). Karakurt ve ark.'nın (41) yaptığı bir çalışmada çalışmamızın aksi yönünde evli hastaların sosyal destek puan ortalamaları daha yüksek bulunmuştur. Evli bireylerin, aile ortamının kalabalık olması ve buna bağlı olarak hastalığına ve hastalığa uyumuna yönelik eleştirilere daha fazla maruz kalması, aile içindeki rollerinden dolayı zaman sıkıntısı gibi nedenlerle sağlık profesyonelleriyle olan ilişkilerini ikinci plana atması bu durumu açıklayabilir.

Eğitim düzeyi düşük hastalar bilgi ve inanç engelleri alt boyutundan daha yüksek puan almışlardır ( $\mathrm{p}<0.05)$ (Tablo 2). Eğitim düzeyi düşük hastaların bilgi düzeylerinin daha düşük olduğu sonucuna varılmıştır. Atmaca ve ark.'nın (42) yaptıkları ve büyük bir çoğunluğunu eğitim seviyesi düşük olan bireylerin oluşturduğu bir çalışmada hastaların yaklaşık olarak yarısında hastalığı ile ilgili bilgi düzeyinin yetersiz veya yanlış olduğu görülmektedir. Başka bir çalışmada düşük eğitim düzeyindeki hastaların diyabetin yönetimi açısından önemli olan HbA1c, LDL ve kan basıncı bilgi düzeylerinin daha düşük olduğu saptanmıştır (43). Eğitim düzeyi, farkındalık için gerekli olan bilgiye daha kolay ulaşmayı sağlayan bir durum olup eğitim düzeyi düşük bireylerin tedaviyi uygulama ve davranış değişikliklerine uyum becerileri daha yetersizdir (42).

Ekonomik duruma göre geliri giderinden az olan hastaların geliri giderine eşit olan hastalara göre daha fazla diyabetle başa çıkma engeli yaşadıkları saptanmıştır $(p<0.05)$ (Tablo 2). Diyabete karşı bu olumsuz tutum diyabet yönetimini de etkilemektedir. Kore'de yapılan bir çalışmada düşük gelirli erkeklerde diyabetik retinopati oranının daha yüksek olduğu bulunmuştur (44). Yorulmaz ve ark.'nın (45) yaptığı çalışmada hastaların sosyoekonomik durumu kötüleştikçe duygusal anlamda daha çok etkilendikleri ve kontrol duygularının azaldığ gözlenmiştir. Bu sonuca göre; gelir seviyesinin artması ile diyabetle başa çıkma engelinin azalması hastaların rahatlama, sağlık koşulları uygun olan ortamda yaşama, hastalığın getirdiği ekonomik yükü karşılayabilme avantajlarıyla bağlantılı olduğu düşünülebilinir.

Hastaların hastalığa ilişkin özellikleri ile hastalık yönetiminde karşılaştıkları engeller değerlendirildiğinde; tanı süresi arttıkça yaşam tarzı değişikliklerinde daha fazla engel yaşadıkları bulunmuştur $(\mathrm{p}<0.05)$ (Tablo 3). Yapılan bir çalışmada tanı süresi atrttıkça öz bakım gücünün azaldığ bulunmuştur. Öz bakım gücünün azalmasıyla birlikte hastanın hastalık uyumunda da bozulmalar meydana gelmektedir. Tanı süresiyle birlikte artan komplikasyon riski hastanın adapte olması gereken yeni durumları doğurur (46). Bu sonuç bir olasılıkla, hastalık süresi uzadıkça bireylerin bir kronik hastalığa sahip olmanın getirdiği sınırlılıkları daha uzun süre yaşamaları, tanı ve tedavi için daha fazla tıbbi girişimlere maruz kalmaları, hastalık semptomlarının artması ve bu durumun yaşam tarzı değişikliliklerine daha zor uyum sağlamaları şeklinde yorumlanabilir.

Çalışmamızda OAD+insülin alan hastaların sadece insülin alan hastalara göre daha fazla öneri ve destek almada engel yaşadıkları bulunmuştur ( $p<0.05)$ (Tablo 3). Hastaların aldıkları destek ve tavsiyeler hastalık yönetiminde yardımcı niteliktedir. Literatür incelendiğinde, bir 
çalışmada insülin alan bireylerin diyabet uyumunun daha iyi olduğu bulunmuştur (47). Yapılan bir çalışmada da OAD kullanan hastaların daha fazla sosyal destek aldıkları bulunmuştur (41). Başka bir çalışmada ise oral antidiyabetik kullanan hastalarla insülin kullanan hastalar arasında sosyal destek yönünden fark bulunamamıştır (48). Sadece insülin tedavisi alan hastalar OAD tedavisine cevap vermeyen yani hastalığın daha fazla ilerlediği hastalardır. Bu nedenle sadece insülin tedavisi alan hastaların daha sıkı kontrolleri söz konusudur. Bu sıkı kontroller sayesinde de sağlık profesyonelleriyle iletişime geçme ve daha fazla öneri ve destek alma imkanı bulmaları bu durumu açıklayabilir.

Diyabet tedavisine uyum algısını kötü ve orta olarak nitelendiren hastaların tedaviye uyumunu iyi kabul eden hastalara göre daha fazla ilaç kullanımı ve sağlık profesyonelleri ile ilişkilerde engel yaşadıkları görülmektedir $(p<0.05)$ (Tablo 3). Yapılan çalışmalarda sağlık profesyonelleriyle ilişkilerde hekim hasta ilişkisi daha ön plana çıkmaktadır. Çalışma bulgumuz literatürle benzerlik göstermektedir (49,50). İbrahim ve ark.'nın (49) İskenderiye'de diyabetli hastalar ile yaptıkları çalışmada hekimleri ile ilişkisi yüksek olan hastaların tedaviye uyumlarının \%93.4 düzeyinde olduğu görülmüştür. Gherman ve ark. (50) tarafından yapılan bir metaanaliz çalışmasında ise hekimi ile iyi ilişkileri olan hastaların tedaviye uyumlarının daha iyi olduğu sonucuna ulaşılmıştır. Bir başka çalışmada da hekimin hastayı bilgilendirmesi ile hastada güven duygusunun oluşması hastanın ilaca uyumunu olumlu yönde etkilediği sonucuna ulaşılmıştır (51).

Çalışmamızda kan şekeri ölçümü yapan hastaların yapmayan hastalara göre kendi kendini izleme engel puanları daha düşük bulunmuştur $(\mathrm{p}<0.05)$ (Tablo 3). Kendi kendini izlem diyabet tedavisinde oldukça önemli bir bileşendir. Bireylerin kan glukoz değerinin yüksek çıkmasından korkması, zaman bulamaması veya ölçüm yapmayı rahatsız edici bulması kan şekeri ölçümü yapmasını engellemektedir.

Hastaların diyetine uyum algısı ile yaşam tarzı değişikliği engelleri, diyabetle başa çıkma engelleri ve öneri ve destek almada engeller alt ölçek grupları ile anlamlı bir ilişki saptanmıştır $(\mathrm{p}<0.05)$ (Tablo 3). Yaşam tarzı değişikliği alt boyutunda hastaların diyet ve egzersiz uyumu, diyabetle başa çıkma engelleri alt boyutunda hastalığa karşı tutumu ve öneri ve destek alama engelleri alt boyutunda çevresinden ve sağlık profesyonellerinden aldığı sosyal destek sorgulanmaktadır. Diyete uyum algısı kötü olan hastalar yaşam tarzı değişikliğinde, diyabetle başa çıkmada, öneri ve destek almada daha fazla engel yaşamaktadırlar. Tip 2 diyabetli kadınlarla yapılan bir çalışmada diyet uyumunda yaşanılan zorluklar dört tema altında toplanmıştır ve bunlardan birisi de destek eksikliği olmuştur (52). Hastalar için aile ve arkadaş desteği hastalıkla mücadelede bir güç kaynağıdır (41). Yapılan bir çalışmada ise hastaların hastalığa karşı olumlu bakış açısı hastalık üzerindeki kontrollerini artırdığı gösterilmiştir (24). Ülkemizde yapılan bir çalışmada pozitif tutuma sahip olanların diyete uyumunun daha iyi olduğu bulunmuştur (53). Hastalığın getirdiği sorumlulukları yerine getirememesi, aile desteğinin olmaması ve hastalığa karşı olumsuz bakış açışı bireyin hastalık yönetimini negatif yönde etkiler ve diyetine uyumunun da bundan etkilenmesi kaçınılmaz olur.

Egzersiz yapma durumuna göre hastalıkla baş etme durumu değerlendirildiğinde egzersiz yapmayan hastaların yapan hastalara göre daha fazla yaşam tarzı değişikliğinde engel yaşadığı görülmektedir $(\mathrm{p}<0.05)$ (Tablo 3$)$. $\mathrm{Bu}$ sonuç, hastaların algıladıkları engeller nedeniyle davranış değişikliği yapmadığını ve egzersizi hayatlarına entegre edemediklerinin göstergesi olarak yorumlanabilir. 
Diyabete bağlı gelişen komplikasyonlara göre hastalıkla başetme durumu incelendiğinde komplikasyon gelişen hastaların bilgi ve inanç engelleri ve diyabetle başa çıkma engelleri puan ortalamalarının daha yüksek olduğu görülmektedir $(p<0.05)$ (Tablo 3). Çalışmamızla uyumlu olarak daha önce yapılan bir çalışmada karşılaşılan problemlerin artması ve hastalığa ilişkin bilgi eksikliğinin negatif tutumun artmasına neden olduğu bildirilmektedir (54). Yapılan başka bir çalışmada da komplikasyon gelişen hastaların diyabet hakkında daha az bilgiye sahip olduğu görülmektedir (55).

Ek hastalığa sahip olan hastalar yaşam tarzı engellerini daha çok yaşamaktadırlar $(\mathrm{p}<0.05)$ (Tablo 3). Yapılan bir çalışmada diyabetlilerde ek hastalı̆̆ fazla olan hastaların diyabete daha az öncelik verdiği ve kendi kendine yönetim beceri puanlarının kötüleştiği bulunmuştur (56). Bireyin birden fazla sorunla mücadele etmesine bağlı olarak uyumunun bozulması bu durumu açıklayabilir.

\section{SONUÇ VE ÖNERİLER}

Tip 2 diyabet hastalarının hastalıkları ile baş etmede karşılaştıkları engelleri değerlendirmek amacıyla yapılan araştırma sonucunda:

-Hastaların DEÖ’nin alt boyutlarında aldıkları puan ortalamalarında en yüksek puan ortalamasının diyabetle başa çıkma alt boyutunun olduğu,

•DEÖ’ nin alt boyutlarından aldıkları puan ortalamalarında en düşük puanı ilaç kullanım alt boyutunun olduğu,

-Kadınların ve kan şekerine bakmayanların kendi kendini izleme engeli yaşadığı,

-50 yaş altında olanların 61 yaş üzerinde olanlara göre daha fazla ilaç kullanım engeli yaşadı̆̆

•Evli olanların, OAD kullananların öneri ve destek almada engel yaşadığ

-Tanı süresi 10 yıl ve üzeri olanların, egzersiz yapmayanların ve ek hastalığı olanların yaşam tarzı değişikliğinde engel yaşadıkları,

•Ekonomik durumu kötü olanların diyabetle başa çıkmada engel yaşadıkları,

-Komplikasyon gelişen ve eğitim düzeyi düşük olan hastaların bilgi ve inanç engeli yaşadıkları,

-Tedaviye uyum algısı kötü ve orta olanların ilaç kullanım ve sağlık profesyonelleriyle ilişkilerde engel yaşadıkları,

-Diyetine uyum algısı kötü olanların yaşam tarzı değişikliğinde, öneri ve destek almada ve diyabetle başa çıkmada engel yaşadığı,

-Metabolik kontrol değişkenlerinden AKŞ, HbA1c, HDL kolesterol, LDL kolesterol, trigliserid ve BKİ ortalamalarının yüksek olduğu,

-AKŞ ile kendi kendini izleme engelleri alt boyutu arasında ters yönde anlamlı ilişki olduğu,

-Diyastolik kan basıncı ile tanıdaki engeller alt boyutu arasında ters yönde anlamlı ilişki olduğu bulunmuştur.

Bu sonuçlar doğrultusunda;

-Hastaların hastalığa karşı tutumlarının değerlendirilmesi ve uygun eğitimlerin verilmesi, 
•Hemşirelerin DM'li hastalara danışmanlık ve bakım verirken sosyodemografik özelliklerini dikkatli bir şekilde analiz etmeleri,

-Kadınların, evlilerin, ekonomik durumu kötü olanların ve eğitim seviyesi düşük olan Tip 2 DM hastalarının hastalık yönetimi konusunda daha fazla desteklenmesi,

-Diyetine uyum algısı kötü olanların yaşam tarzı değişikliği konusunda bilgilendirilmesi ve desteklenmesi,

-DM hastalarına geniş kapsamlı bir değerlendirme yapılarak fiziksel, sosyal ve psikolojik yönden yaşanan sorunların saptanarak desteklenmesi,

•DM hastalarının, düzenli kan şekeri ölçümü yapma, sonuçları değerlendirme ve uygun girişimde bulunmaları açısından daha fazla eğitime tabi tutulması,

-Konuyla ilgili olarak daha fazla bilimsel çalışma yapılması önerilmektedir.

\section{Araştırmanın Etik Yönü}

Araştırmaya başlanmadan önce araştırmanın yapılabilmesi için Atatürk Üniversitesi Tıp Fakültesi Etik Kurulu Başkanlığı' ndan ( 30.05 .2019 tarihli, B.30.2.ATA.0.01.00/341 sayıl1) etik kurul onayı alınmıştır. Daha sonra araştırmanın yapılacağı Atatürk Üniversitesi Sağlık Araştırma ve Uygulama Merkezi' 'nden gerekli kurum izni alınmıştır. Araştırmaya katılan tip 2 diyabet hastalarına çalışmanın amacı açıklanarak ve aydınlatılıııs onamları alınarak veriler toplanmıştır.

\section{Çıkar Çatışması}

Yazarlar arasında çıkar çatışması yoktur.

\section{KAYNAKLAR}

1. Akalın, S. (2015). Diabetes Mellitus sınıflaması ve tanı. İçinde: İmamoğlu Ş., Satman İ., Akalın S., Salman S., Yılmaz C (Ed.), Geçmişten geleceğe Diabetes Mellitus (1723). Ankara: Baty.

2. Tanrıverdi, M. H., Çelepkolu, T., \& Aslanhan, H. (2013). Diyabet ve birinci basamak sağlık hizmetleri. Journal of Clinical \& Experimental Investigations, 4(4).

3. International Diabetes Federation, 2019 Diabetes Atlas. https://diabetesatlas.org/upload/resources/2019/IDF_Atlas_9th_Edition_2019.pdf. (Erişim Tarihi: 20 Kasım 2019).

4. Sağlık Bakanlığg Türkiye Halk Sağlı̆̆ Kurumu. 2015-2020 Türkiye diyabet programı. 2.Bask1, 2014: 1-66.

5. Olgun, N., Aslan, F. E., Coşansu, G., Çelik, S. (2017). Diabetes Mellitus. Karadakovan A., Aslan F.E. (Ed.). Dahili ve cerrahi hastalıklarda bakım (ss. 767-804). Ankara: Akademisyen Kitabevi. ss. 767-804).

6. Uluslararası Diyabet Liderler Zirvesi. Türkiye'de ve bölge ülkelerinde diyabet sorunu. http://www.diabetcemiyeti.org/c/turkiye-de-ve-bolge-ulkelerinde-diyabet-sorunu. (Erişim Tarihi: 15 Nisan 2019).

7. Özdemir, İ., Hocaoğlu, Ç. (2009). Tip 2 diabetes mellitus ve yaşam kalitesi: Bir gözden geçirme. Göztepe Tıp Dergisi, 24, 73-78. 
8. Üren, Y., Karabulutlu, E. Y. (2018). Tip 2 diyabet hastalarında diyabet kontrolünü zorlaştıran faktörlerin incelenmesi. Sağllk Bilimleri ve Meslekleri Dergisi, 5(3), 376386.

9. Chew, B. H., Khoo, E. M., Chia, Y. C. (2015) Social support and glycemic control in adult patients with type 2 diabetes mellitus. Asia Pacific Journal of Public Health, 27, 166-173.

10. Boussageon, R., Gueyffier, F., Cornu, C. (2014). Effects of pharmacological treatments on micro-and macrovascular complications of type 2 diabetes: what is the level of evidence? Diabetes \& Metabolism, 40, 169-175.

11. Song, M. S., Kim, H. S. (2009). Intensive management program to improve glycosylated hemoglobin levels and adherence to diet in patients with type 2 diabetes. Applied Nursing Research, 22, 42-47.

12. Gergely, M. (1992). Effective diabetes education. IDF Bulletin, 37, 9-10

13. Kahraman, G., Tavşanlı, N. G., Baydur, H., Özmen, D., Özmen, E. (2016). Tip-2 diyabet hastalarında diyabette engeller ölçeğinin geçerlilik ve güvenilirlik çalışması. Anadolu Psikiyatri Dergisi, 17,33-44.

14. American Diabetes Association. (2016). Glycemic Targets. Diabetes Care, 39,39-46.

15. Polonsky, W. H., Fisher, L., Schikman, C. H., Hinnen, D. A., Parkin, C. G., Jelsovsky, Z. (2011). Structured self monitoring of blood glucose significantly reduces A1C levels in poorly controlled, noninsulin-treated type 2 diabetes: results from the structured testing program study. Diabetes Care, 34(2) ,262-267.

16. Aslan, D., Yılmaztürk, G. C., Akalın, N., Büyükbeşe, M. A., Sermez, Y., Fenkçi, S. (2011). Klinik laboratuvar test sonuçlarının uluslararası ve ulusal harmonizasyonu, standardizasyonu ve HbA1c örneği. Türk Biyokimya Dergisi, 36(4), 374-383.

17. İnkaya, V. B., Karadağ, E. (2017). Diyabetli bireyler ve onlara bakım veren hemşirelerin hastalık özyönetim stratejilerine bakışı: Kalitatif bir çalışma. HEAD, 14(1), 31-37.

18. American Diabetes Association. (2014). Standarts of medical care in diabetes. Diabetes Care, 37,14-80.

19. Kartal, A., Çağırgan, M. G., Tı̆̆lı, H., Güngör, Y., Karakuş, N., Gelen, M. (2008) Tip 2 diyabetli hastaların bakım ve tedaviye yönelik tutumları ve tutumu etkileyen faktörler. TAF Prev Med Bull, 7(3), 223-230.

20. El-Kebbi, I. M., Bacha, G. A., Ziemer, D. C. (1996). Diabetes in urban African Americans: use of discussion groups to identify barriers to dietary therapy among lowincome individuals with non-insulin dependent diabetes mellitus. Diabetes Educ, 22(5),488-492.

21. Maillet, N. A., Melkus, G. D., Spollett, G. (1996). Using focus groups to characterize the health beliefs and practices of black women with non-insulin-dependent diabetes. Diabetes Educ, 22(1), 39-46.

22. Peyrot, M., Rubin, R. R., Lauritzen, T., Snoek, F. J., Matthews, D. R., Skovlund, S. E. (2005). Psychosocial problems and barriers to improved diabetes management: results of the cross-national diabetes attitudes, wishes and needs (dawn) study. Diabetic medicine, 22(10), 1379-1385.

23. Byers, D., Garth, K., Manley. D., Chlebowy, D. (2016). Facilitators and barriers to type 2 diabetes self-management among rural African American adults. Journal of Health Disparities Research and Practice, 9(1), 164-174.

24. Nagelkerk, J., Reick, K., Meengs, L. (2006). Perceived barriers and effective strategies to diabetes self-management. Journal of advanced nursing, 54(2), 151-158.

25. Ghimire, S. (2017). Barriers to diet and exercise among nepalese type 2 diabetic patients. International Scholarly Research Notices, 84, 1-9. 
26. Özcan, Ş. (1999). Diyabetli hastalarda hastalı̆̆a uyumu etkileyen faktörlerin değerlendirilmesi. (Yayınlanmamış Doktora Tezi). İstanbul Üniversitesi Sağlık Bilimleri Enstitüsü, İstanbul.

27. Hearnshaw, H., Wright, K., Dale, J., Sturt, J., Vermeire, E., Royen Van, P. (2007). Development and validation of the Diabetes Obtacles Questionnaire (DOQ) to assess obstacles in living with type 2 diabetes. Diabetic Med, 24(8), 878-882.

28. Kara, K., Çınar, S. (2011). Diyabet bakım profili ile metabolik kontrol değișkenleri arasındaki ilișki. Kafkas J Med Sci, 1(2),57-63.

29. Al-Maskar1, F., El-Sadig, M., Al-Kaabi, J. M., Afandi, B., Nagelkerke, N., Yeatts, K. B. (2013). Knowledge, attitude and practices of diabetic patients in the United Arab Emirates. PloS one, 8(1), 1-8.

30. Herath, H., Weerasinghe, N. P., Dias, H., Weerarathna, T. P. (2017). Knowledge, attitude and practice related to diabetes mellitus among the general public in Galle district in Southern Sri Lanka: A pilot study. BMC Public Health, 17(1), 535-7.

31. Baradaran, H., Knill-Jones, R. (2004). Assessing the knowledge, attitudes and understanding of type 2 diabetes amongst ethnic groups in Glasgow, Scotland. Practical Diabetes International, 21(4), 143-148.

32. Boccuzzi, S. J., Wogen, J., Fox, J., Sung, J. C. Y., Shah. A. B., Kim. J. (2001). Utilization of oral hypoglycemic agents in a drug-insured U.S. population. Diabetes Care, 24(8), 1411-1415.

33. Cunningham, V., Mohler, M. J., Wendel, C. S., Hoffman, R. M., Murata, G. H., Shah, J. H., et al. (2005). Reliability and validity of the DCP among hispanic veterans. Evaluation \& the health professions, 28(4), 447-463.

34. Li, J., Li, Z., Zhao, W., Pan, H., \& Halloran, E. J. (2015). The reliability and validity of the Diabetes Care Profile for Chinese populations. Evaluation \& the health professions, $38(2), 200-218$.

35. Günay, G., \& Bener, Ö. (2011). Kadınların toplumsal cinsiyet rolleri çerçevesinde aile içi yaşamı algılama biçimleri. Türkiye Sosyal Araştırmalar Dergisi, 153(153).

36. Garay-Sevilla, M. E., Nava, L. E., Malacara, J. M., Huerta, R., de León, J. D., Mena, A., et al. (1995). Adherence to treatment and social support in patients with non-insulin dependent diabetes mellitus. Journal of Diabetes and its Complications, 9(2), 81-86.

37. Kim, K. C., Kim, J. T., Kim, J. S., Cho, H. S., Shim, J. Y., \& Lee, H. R. (1999). Medication compliance in the elderly and the factors associated with compliance. Journal of the Korean Academy of Family Medicine, 20(10), 1216-1223.

38. Sweileh, W. M., Sa'ed, H. Z., Nab'a, R. J. A., Deleq, M. I., Enaia, M. I., Sana'a, M. N., et al. (2014). Influence of patients' disease knowledge and beliefs about medicines on medication adherence: findings from a cross-sectional survey among patients with type 2 diabetes mellitus in Palestine. BMC public health, 14(1), 1-8.

39. Park, K. A., Kim, J. G., Kim, B. W., Kam, S., Kim, K. Y., Ha, S. W., et al. (2010). Factors that affect medication adherence in elderly patients with diabetes mellitus. Korean Diabetes Journal, 34(1), 55.

40. Canpolat, M. (2018). Diyabetik ayak gelişen hastalarda algılanan sosyal destek ile yaşam kalitesi arasındaki ilişkinin belirlenmesi. (Yayınlanmamış Yüksek Lisans Tezi). İnönü Üniversitesi Sağlık Bilimleri Enstitüsü, MALATYA.

41. Karakurt, P., Aşılar, R. H., \& Yıldırım, A. (2013). Evaluation of the self-care agency and perceived social support in patients with diabetes mellitus. Meandros Medical and Dental Journal, 14(1), 1-9.

42. Atmaca, H. U., Akbaş, F., Şak, T., Şak, D. U., Acar, Ş., \& Niyazoğlu, M. (2015). Diyabetik hastalarda hastalık bilinç düzeyi ve farkındalık. Istanbul Medical Journal, 16(3). 
43. Casagrande, S. S., Burrows, N. R., Geiss, L. S., Bainbridge, K. E., Fradkin, J. E., \& Cowie, C. C. (2012). Diabetes knowledge and its relationship with achieving treatment recommendations in a national sample of people with type 2 diabetes. Diabetes Care, 35(7), 1556-1565.

44. Kim, S. H., Lee, S. Y., Kim, C. W., Suh, Y. J., Hong, S., Ahn, S. H., et al. (2018). Impact of socioeconomic status on health behaviors, metabolic control, and chronic complications in type 2 diabetes mellitus. Diabetes \& metabolism journal, 42(5), 380.

45. Yorulmaz, H., Tatar, A., Saltukoğlu, G., \& Soylu, G. (2013). Diyabetli hastalarda hastalık algısını etkileyen faktörlerin incelenmesi. FSM İlmî Araştırmalar İnsan ve Toplum Bilimleri Dergisi, 0(2), 367-387.

46. Özkan, S., Durna, Z. (2006). İnsüline bağımlı diyabetli hastalarda öz-bakım gücünün belirlenmesi. Ege Üniversitesi Hemşirelik Fakültesi Dergisi, 22(2), 121-135.

47. Kasznicki, J., Głowacka, A., \& Drzewoski, J. (2007). Type 2 diabetic patients compliance with drug therapy and glycaemic control. Diabetologia Doświadczalna $i$ Kliniczna, 7(4), 199-198.

48. Yildiz, E., Aşti, T. (2015). Determine the relationship between perceived social support and depression level of patients with diabetic foot. Journal of Diabetes \& Metabolic Disorders, 14(1), 1-8.

49. Ibrahim, N. K. R., Attia, S. G., Sallam, S. A., Fetohy, E. M., \& El-Sewi, F. (2010). Physicians' therapeutic practice and compliance of diabetic patients attending rural primary health care units in Alexandria. Journal of Family and Community Medicine, 17(3), 121.

50. Gherman, A., Schnur, J., Montgomery, G., Sassu, R., Veresiu, I., \& David, D. (2011). How are adherent people more likely to think? A meta-analysis of health beliefs and diabetes self-care. The Diabetes Educator, 37(3), 392-408.

51. Levesque, A., Li, H. Z., Pahal, J. S. (2012). Factors related to patients' adherence to medication and lifestyle change recommendations: Data from Canada. International Journal of Psychological Studies, 4(2), 42.

52. Murrock, C. J., Taylor, E., \& Marino, D. (2013). Dietary challenges of managing type 2 diabetes in African-American women. Women \& health, 53(2), 173-184.

53. Ustaalığlu, S., Tan, M. (2017). Tip 2 diyabetli hastaların bakım ve tedaviye yönelik tutum ve davranışlarının incelenmesi. Gümüşhane Üniversitesi Sağllk Bilimleri Dergisi, 6(4), 12-20.

54. Elkoca A. (2010). Tip 2 diyabetli hastaların hastalı̆̆a karşı tutumları ve problem alanlar arasındaki ilişkinin incelenmesi. (Yayınlanmamış Yüksek Lisans Tezi). Atatürk Üniversitesi Sağlık Bilimleri Enstitüsü, ERZURUM.

55. Hawthorne, K., \& Tomlinson, S. (1999). Pakistani moslems with Type 2 diabetes mellitus: effect of sex, literacy skills, known diabetic complications and place of care on diabetic knowledge, reported self-monitoring management and glycaemic control. Diabetic Medicine, 16(7), 591-597.

56. Kerr, E. A., Heisler, M., Krein, S. L., Kabeto, M., Langa, K. M., Weir, D., et al. (2007). Beyond comorbidity counts: how do comorbidity type and severity influence diabetes patients' treatment priorities and self-management?. Journal of general internal medicine, 22(12), 1635-1640. 